\title{
Full scale laboratory experiment on the cooling capacity of a radiant floor system
}

Pantelic, Jovan; Schiavon, Stefano; Ning, Baisong; Bourdakis, Eleftherios; Raftery, Paul; Bauman, Fred

Published in:

Energy and Buildings

Link to article, DOI:

10.1016/j.enbuild.2018.03.002

Publication date:

2018

Document Version

Peer reviewed version

Link back to DTU Orbit

Citation (APA):

Pantelic, J., Schiavon, S., Ning, B., Bourdakis, E., Raftery, P., \& Bauman, F. (2018). Full scale laboratory experiment on the cooling capacity of a radiant floor system. Energy and Buildings, 170, 134-144.

https://doi.org/10.1016/j.enbuild.2018.03.002

\section{General rights}

Copyright and moral rights for the publications made accessible in the public portal are retained by the authors and/or other copyright owners and it is a condition of accessing publications that users recognise and abide by the legal requirements associated with these rights.

- Users may download and print one copy of any publication from the public portal for the purpose of private study or research.

- You may not further distribute the material or use it for any profit-making activity or commercial gain

- You may freely distribute the URL identifying the publication in the public portal 


\section{Accepted Manuscript}

Full scale laboratory experiment on the cooling capacity of a radiant floor system

Jovan Pantelic, Stefano Schiavon, Baisong Ning , Eleftherios Burdakis, Paul Raftery, Fred Bauman

PII: S0378-7788(17)33441-2

DOI: 10.1016/j.enbuild.2018.03.002

Reference: $\quad$ ENB 8388

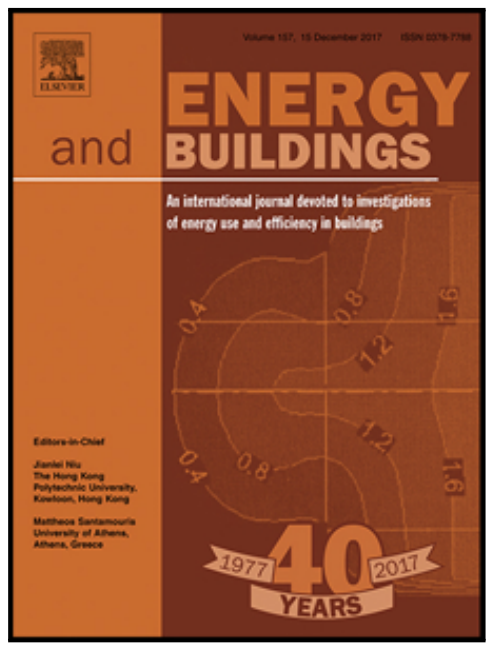

To appear in:

Energy \& Buildings

Received date: 16 October 2017

Revised date: 30 January 2018

Accepted date:

1 March 2018

Please cite this article as: Jovan Pantelic, Stefano Schiavon, Baisong Ning, Eleftherios Burdakis , Paul Raftery, Fred Bauman, Full scale laboratory experiment on the cooling capacity of a radiant floor system, Energy \& Buildings (2018), doi: 10.1016/j.enbuild.2018.03.002

This is a PDF file of an unedited manuscript that has been accepted for publication. As a service to our customers we are providing this early version of the manuscript. The manuscript will undergo copyediting, typesetting, and review of the resulting proof before it is published in its final form. Please note that during the production process errors may be discovered which could affect the content, and all legal disclaimers that apply to the journal pertain. 


\section{Highlights}

- The cooling capacity of the chilled radiant floor was measured to increase from 32 up to $110 \mathrm{~W} / \mathrm{m}^{2}$ under direct solar radiation.

- The surface temperature region exposed to solar radiation reached a peak temperature of $26^{\circ} \mathrm{C}$ while the unexposed areas were between 20 and $21^{\circ} \mathrm{C}$.

- Increasing the chilled water supply temperature from 12 to $18{ }^{\circ} \mathrm{C}$ caused a decrease in cooling capacity from $\sim 110$ to $\sim 95 \mathrm{~W} / \mathrm{m}^{2}$.

- Higher air speeds along the floor created by ceiling fans increased the radiant slab cooling capacity by $\sim 12 \%$ (from 32 to $36 \mathrm{~W} / \mathrm{m}^{2}$ ) when the operative temperature was 24 ${ }^{\circ} \mathrm{C}$ and, up to $\sim 19 \%\left(40 \mathrm{~W} / \mathrm{m}^{2}\right)$ when it is increased to $26{ }^{\circ} \mathrm{C}$.

- The presence of thin carpet tiles marginally reduced the radiant floor cooling capacity ( $5 \%$ ) compared to an exposed floor slab. 


\title{
Full scale laboratory experiment on the cooling capacity of a radiant floor system
}

\author{
Jovan Pantelic $^{1}$, Stefano Schiavon ${ }^{1}$, Baisong Ning ${ }^{1,2}$, Eleftherios Burdakis ${ }^{1,3}$, Paul Raftery ${ }^{1}$, Fred
} Bauman $^{1}$

${ }^{1}$ Center for the Built Environment, University of California, Berkeley

${ }^{2}$ College of Civil Engineering, Hunan University

${ }^{3}$ International Center for the Indoor Environment and Energy, Technical University of Denmark

\begin{abstract}
Direct solar radiation on a cooled radiant floor increases its cooling capacity. There is limited measured evidence of this phenomenon reported in the literature. We assessed the effect of solar radiation, increased air movement, and carpet on the cooling capacity of the radiant floor in a laboratory exposed to the outside environment. We performed experiments for different chilled water supply temperature. The cooling capacity of the chilled radiant floor was measured to increase from 32 up to $110 \mathrm{~W} / \mathrm{m}^{2}$ under direct solar radiation. The surface temperature region exposed to solar radiation reached a peak temperature of $26^{\circ} \mathrm{C}$ while the unexposed areas were between 20 and $21{ }^{\circ} \mathrm{C}$. Increasing the chilled water supply temperature from 12 to $18{ }^{\circ} \mathrm{C}$ caused a decrease in cooling capacity from $\sim 110$ to $\sim 95 \mathrm{~W} / \mathrm{m}^{2}$. Higher air speeds along the floor created by ceiling fans increased the radiant slab cooling capacity by $\sim 12 \%$ (from 32 to $36 \mathrm{~W} / \mathrm{m}^{2}$ ) when the operative temperature was $24{ }^{\circ} \mathrm{C}$ and, up to $19 \%\left(40 \mathrm{~W} / \mathrm{m}^{2}\right)$ when it is increased to $26{ }^{\circ} \mathrm{C}$. The presence of thin carpet tiles reduced the radiant floor cooling capacity for $\sim 5 \%$ compared to an exposed floor slab.

\section{Introduction}

Radiant floor cooling can be used in building spaces with large glazed surfaces designed to allow direct penetration of sun and daylight, for example, atriums, airports, and entrance halls. Some of the applications of radiant floor cooling systems include Hearst Tower in New York, Akron art museum in Ohio, and Suvarnabhumi Airport in Bangkok, Thailand (Simmonds et al., 2006).
\end{abstract}

When compared to conventional all-air systems, radiant floor cooling offers several advantages: (i) higher energy efficiency (Stetiu, 1999; Watson and Chapman, 2002) especially through high temperature cooling (Meggers et al., 2012, 2013), (ii) application of non-compressor-based energy sources like geothermal and evaporative cooling (Meggers et al., 2013; Ren et al., 2010), (iii) equal or better thermal comfort than air systems (Karmann et al., 2017b; Karmann paper under review), (iv) reduction of circulation energy for water vs. air (Feustel and Stetiu, 1995), (v) the ability of load shifting from daytime to nighttime (Olesen, 2000), (vi) reduction of peak energy demand (Gwerder et al., 2008), and (vii) material and spatial savings through slab and ceiling integration (Kiel 2010; Schlueter et al., 2016). Radiant systems pose also some challenges: (i) thermally massive systems with large exposed concrete surfaces may lead to higher reverberation time and therefore proper acoustical treatment is needed. Acoustical cloud 
coverage of $\sim 30 \%$ of the ceiling in a private office or $\sim 50 \%$ in an open plan office creates sufficiently acceptable sound absorption conditions with a reduction of only $\sim 10 \%$ of cooling capacity (Karmann et al., 2017a); (ii) in humid climates there is a need to control humidity to avoid the risk of condensation (Mumma, 2002; Tang et al., 2016) (iii) high thermal mass radiant systems have a large response time (on the order of hours), which can require more challenging control strategies to fully take advantage of (Ning et al., 2017); (iv) floor carpet and furniture coverage will reduce cooling capacity.

Chilled radiant floors are able to instantaneously remove radiant heat (long and short wave) from external (solar) or internal heat sources, as well as an interior surface within its line-of-sight view. All-air systems remove heat gain from the space through convection, while radiant floors remove heat gain from the zone through radiant heat transfer between external and internal heat sources and convection from the warmer indoor air. A range of radiant floor cooling capacities has been reported in the literature for two distinct scenarios, with and without direct solar load. Olesen (1997) reported that radiant floor cooling capacity range is $35-50 \mathrm{~W} / \mathrm{m}^{2}$, but for cases with direct sunshine on the floor, the cooling capacity rangés from $100-150 \mathrm{~W} / \mathrm{m}^{2}$. Simmonds et al. (2000) reported that $70-80 \mathrm{~W} / \mathrm{m}^{2}$ was used as an average cooling capacity for mixed loads in the Bangkok airport design. The two works mentioned above did not provide measured evidence of their claims. Odyjas and Górka, (2013) simulated different thermal loads in the space and reported that floor cooling capacities for convective loads range from 22 to $28 \mathrm{~W} / \mathrm{m}^{2}$, for mixed loads range from 39 to $50 \mathrm{~W} / \mathrm{m}^{2}$ and for direct solar load they range from 68 to $86 \mathrm{~W} / \mathrm{m}^{2}$ for the floor surface temperature between 22 and $23.5^{\circ} \mathrm{C}$. In their review paper, Zhao et al. (2013), without citing the source of this information, suggest that for buildings with large glass surfaces, cooling capacity of the radiant floor can reach 60 to $120 \mathrm{~W} / \mathrm{m}^{2}$ and for buildings with less glazing and direct solar penetration, cooling capacities are 35 to $40 \mathrm{~W} / \mathrm{m}^{2}$. Measurements of radiant floor cooling capacity in Xi' an Xianyang International Airport (Zhao et al., 2014) showed cooling capacities from 25 to $40 \mathrm{~W} / \mathrm{m}^{2}$ in areas with no direct solar exposure and 110 to $140 \mathrm{~W} / \mathrm{m}^{2}$ in locations directly exposed to the solar radiation. Feng et al., 2016 used EnergyPlus to simulate a total of 864 cases in which the window-to-wall ratio, building orientation, shading options and floor absorptivity varied, and concluded that radiant floor cooling capacity can vary between 20 and $44 \mathrm{~W} / \mathrm{m}^{2}$ without solar, and can go up to $150 \mathrm{~W} / \mathrm{m}^{2}$ with direct solar. Feng et al., 2016 also compared simulated capacities with the capacities calculated with ISO calculation method (ISO 2012) and concluded that the capacity is 1.2 to 2.7 times higher for the cases when floor is exposed to direct solar.

Changing the convective coefficient can influence cooling capacity of the radiant floor. The convective coefficient can be increased with the use of ceiling fans that create boundary layer flow across the floor surface (Gao et al., 2017). Boundary layer flow across the floor has higher velocity compared to the flow field established in the indoor environment without ceiling fans. To the best of our knowledge impact of the use of ceiling fans on floor cooling capacity have not 
been quantified. Karmann et al., (2017 - submitted for publication) showed that the use of fans between a radiant chilled ceiling and acoustical canopies mounted below them can increase cooling output of the radiant ceiling by up to $20 \%$.

In commercial buildings floors are often covered with carpet tiles. From a heat transfer perspective, carpet tiles present additional thermal resistance. Additional resistance reduces cooling capacity of the floor. The effect of the additional thermal resistance is especially important if areas of the floor that will be carpeted are known during the design stage. This phenomenon has been extensively tested with simulation, but it has not been quantified experimentally.

In this study, "cooling capacity" is the heat flux on the surface of the slab. We need to distinguish this term from the hydronic cooling capacity that refers to the amount of heat that is exchanged between the slab and hydronic tubing. A wide ranges of cooling eapacities under solar radiation have been reported based on engineering judgment $\left(100-150 \mathrm{~W} / \mathrm{m}^{2}\right.$ in Olesen, 1997 ; numerical calculations (up to $150 \mathrm{~W} / \mathrm{m}^{2}$ (Feng et al., 2016)), and field studies (110-140 W/m² (Zhao et al., 2014)). All the studies point out that cooling capacity of chilled radiant floors exposed to direct solar radiation require special consideration. To our knowledge, laboratory measurement of floor cooling capacity has not been previously conducted or reported. The objective of this study was to measure, in a highly controlled laboratory facility with outdoor solar exposure, the effect on radiant floor cooling capacity of: (1) direct solar radiation exposure; (2) elevated air movement caused by ceiling fans; and (3) presence of carpet tiles.

\section{Experimental methods}

\subsection{Measurement equipment}

We conducted experiments in chamber 3B of FLEXLAB ${ }^{\circledR}$ (https://flexlab.lbl.gov/) at Lawrence Berkeley National Laboratory (LBNL). Chamber 3B (Figure 1) has dimensions of 6.4 x $9.64 \mathrm{~m}$ and is equipped with an embedded PEX tubing floor cooling system consisting of seven water loops. The PEX tubing (0.0159 m diameter) is attached to the rebar at a depth of $0.05 \mathrm{~m}$ in the concrete floor slab, with $0.15 \mathrm{~m}$ of concrete below, followed by foam insulation $(0.15 \mathrm{~m}$ thick) which separates the concrete slab from the ground. The water loops are distributed across the floor with the objective to create a uniform slab temperature distribution. We measured slab temperature with in-slab temperature sensors positioned in the middle of the $3 \mathrm{~B}$ chamber. The vertical position of the sensors is $0.05 \mathrm{~m}$ below PEX tubes. Another in-slab temperature sensor was positioned just above the foam insulation. The rated accuracy of the in-slab temperature sensors is $\pm 0.05{ }^{\circ} \mathrm{C}$. The windows in the $3 \mathrm{~B}$ chamber are on the south wall at $0.8 \mathrm{~m}$ height from the floor along the full width of the wall, which is oriented South. The low-e double-pane glass windows were built in compliance with ASHRAE Standard 90.1 (2010) with SHGC of 0.25 and $\mathrm{U}$-value $=3.4 \mathrm{~W} /\left(\mathrm{m}^{2} \cdot \mathrm{K}\right)$. Thermistors were mounted on the inner side of the inner glass pane $\left(4^{\text {th }}\right)$ to measure glass surface temperature and enable estimation of amount of heat in the long wave spectra irradiated towards the interior. A weather station, containing an air temperature 
sensor, a humidity sensor, a pyranometer for measurements of total and diffuse solar irradiance, and a wind speed and direction sensor, was mounted on the roof of the $3 \mathrm{~B}$ chamber.

We installed three pyranometers (Epplet, SPP), recording at 1 min interval, inside 3B in different locations to measure solar radiation. The pyranometers measure solar radiation wavelength ranging from 0.295 to $2.8 \mu \mathrm{m}$, capturing visible and near infrared spectra. This range contains approximately $99 \%$ of the solar radiation at the earth's surface. The standard measurement uncertainty is $3.5 \%$ and the response time is $5 \mathrm{~s}$. We calibrated each pyranometer before they were deployed.

We used omnidirectional air speed probes with a range of 0.05 to $5 \mathrm{~m} / \mathrm{s}$ to measure air speed. The measurement accuracy of the air speed probes is $1 \%$ of the reading or $0.02 \mathrm{~m} / \mathrm{s}$ in the range of 0.05 to $1 \mathrm{~m} / \mathrm{s}$. This was the range of velocities during our experiment. We measured surface temperature with $k$-type thermocouples. Measurement accuracy was with special limits of \pm 1.1 ${ }^{\circ} \mathrm{C}$ or $2 \%$ of the reading. We measured air and operative temperature with an accuracy of $0.2{ }^{\circ} \mathrm{C}$ or $2 \%$ of the reading. We measured airflow with an in ductinstalled airflow meter with an accuracy of $3 \%$ of the reading. We measured s air temperature in the supply and return duct with the accuracy of $\pm 0.2{ }^{\circ} \mathrm{C}$. We measured supply water flow rate with accuracy of $2 \%$ of the reading. We measured supply and return chilled water temperature with accuracy of $\pm 0.2{ }^{\circ} \mathrm{C}$.

We mounted heat flux sensors at selected locations on the floor surface, applying thermal sink paste on the bottom sensor surface to increase thermalconductivity between heat flux sensor and the floor surface. We covered the top part of the sensor with black tape. The large area heat flux (FluxTeq, PHFS-09e ), $\mathrm{HFb}$, sensor (Figure $1 \mathrm{~b})$ is $88 \times 95 \mathrm{~mm}$ in size $\left(84 \mathrm{~cm}^{2}\right.$ of sensing area) and uses a differential temperature thermopile with a response time of $0.9 \mathrm{~s}$. The measurement accuracy was $2.5 \%$. In addition to these large sensors, we also used smaller heat flux (FluxTeq, PHFS-01e), HFs, sensors to further increase the resolution of heat flux measurements on the floor surface, as shown in Figure 1B. This smaller heat flux sensor has a total sensing area of $6.45 \mathrm{~cm}^{2}$, a response time of $0.9 \mathrm{~s}$ and a measurement accuracy of $5 \%$. We used a Labjack data logger combined with a terminal board to acquire data from the sensors. The Labjack data logger analog inputs can measure differences of up to $\pm 0.01 \mathrm{~V}$, and the heat flux sensors were directly connected to the data logger.

\subsection{Experimental conditions and procedures}

During the experiments, we used a combination of a constant volume air system and floor cooling to maintain the operative temperature setpoint. We based the decision to use operative temperature on conclusions derived from simulation and experimental work by Feng et al., 2013 and Feng et al., 2014. We calculated the average operative temperature based on the readings of three operative temperature sensors positioned at $0.6 \mathrm{~m}$ from the floor. We placed these operative temperature sensors (Figure 1b) along the chamber centerline and they were not exposed to the direct solar radiation. The total amount of interior heat loads in the space was $3630 \mathrm{~W}\left(61 \mathrm{~W} / \mathrm{m}^{2}\right.$ 
floor area) distributed with six dominantly radiant heaters (200 W each) and two convective heaters $(750 \mathrm{~W}$ each), four thermal manikins resembling building occupants ( $75 \mathrm{~W}$ each) and four thermal cylinders (120 W each). 

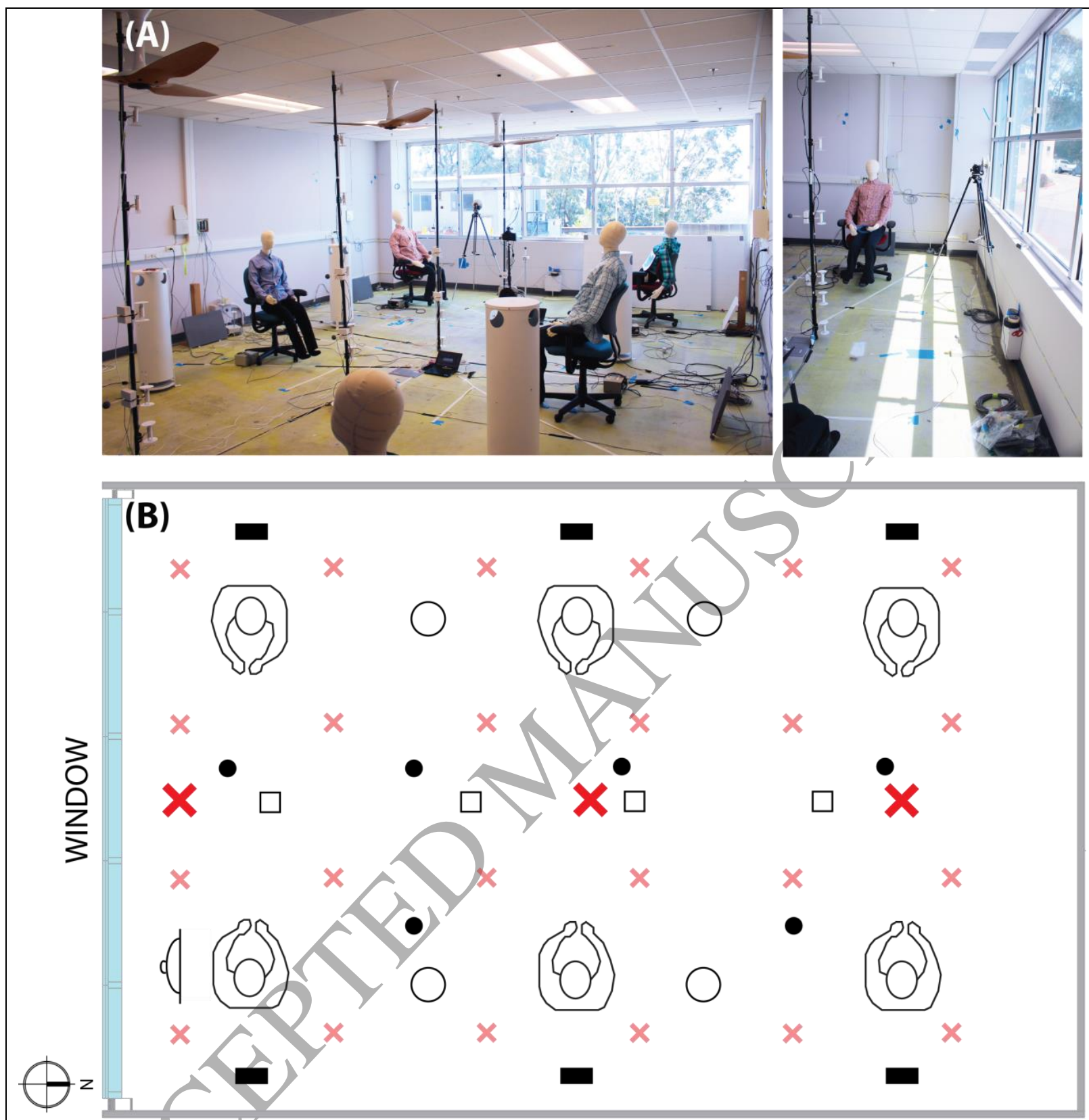

\section{DIMENSIONS: 3 × $10 \mathrm{~m}$}

Big heat flux sensor

$\times$ Small heat flux sensor

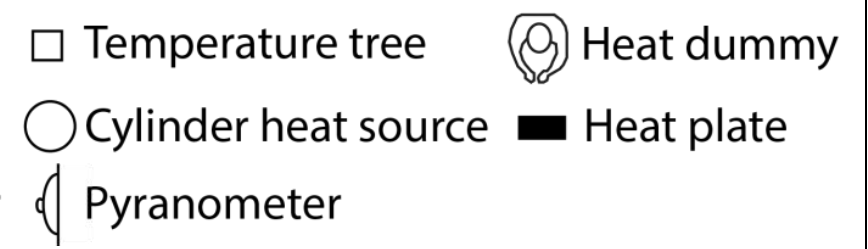

- Surface temperature sensor

Figure 1. Experimental setup. (a) Full chamber (left) and zoom in on the sun exposed region (right), (b) measurement and equipment distribution plan. 
Since solar radiation entered through the south facing window, the floor area was divided into two parts: the part that was exposed to the direct solar and the part that was not. We located the three larger, more accurate heat flux sensors strategically in order to capture this phenomenon: south $\left(H F_{b, \text { south }}\right)$ - close to the window, on the chamber centerline $\left(H F_{b, \text { middle }}\right)$ - on the chamber centerline in the middle of the chamber, north $\left(H F_{b, n o r t h}\right)$ - close to the north wall opposite of the window on the chamber centerline (Figure 1b). We then located a grid of 24 heat flux sensors, nine surface temperature thermocouples and two pyranometers (Figure 1b) on the floor surface to measure surface heat flux, surface slab temperature and solar irradiance reaching the floor.

We measured air speed, air temperature and operative temperature at heights of $0.1,0.3,0.6,1.1$, 1.7 and $2.1 \mathrm{~m}$ from the floor (ISO 7726, ISO 7730, ASHRAE Standard 55) along the centerline of the chamber to monitor possible stratification and heterogeneity of indoor conditions, both of which might impact floor cooling capacity. We positioned three measurement trees across the centerline of the chamber to enable proper comparison between chamber conditions. Table 1 shows the experimental conditions for the 22 individual experiments that we performed.

Table 1. Experimental test conditions

\begin{tabular}{cccc}
\hline & $T_{o p}\left[{ }^{o} \mathrm{C}\right]$ & $T_{w i}\left[{ }^{o} \mathrm{C}\right]$ & Window \\
\hline Concrete slab & 24 & $12,13.5,15,16.5,18$ & $\begin{array}{c}\text { Open } \\
\text { Blocked }\end{array}$ \\
\hline \multirow{2}{*}{ Ceiling fans } & 24 & $15,16.5,18$ & Blocked \\
\hline Carpet tiles & 26 & $12,13.5,15$ & $\begin{array}{c}\text { Open } \\
\text { Blocked }\end{array}$ \\
\hline
\end{tabular}

\subsection{Measurement Uncertainty}

Three components of multiple measurement error are absolute constant error, conditionally constant error and random error. Absolute constant errors have a constant value that is the same in all the measurements and it is unknown. In a measurement, rarely more than one or two absolutely constant errors exist, and they are, as a rule, insignificant. Absolute constant error can be considered as 0 . Conditionally constant error, $\vartheta_{o}$, accounts for the intrinsic measurement error of the instruments and additional elementary errors (e.g., experimental procedure error or putting the tape over the top surface of the heat flux meter), $\vartheta_{i}$. For floor cooling capacity measurement: $\vartheta_{a}=k_{a} * \sqrt{\vartheta_{0}^{2}+\vartheta_{i}^{2}}=1.12 * \sqrt{2.5^{2}+2.5^{2}}=3.96 \% . k_{a}$ is coefficient for various number of component errors. Rabinovich (2013) suggests a value of 1.12. Random error is calculated using: $\psi_{0.95}=t_{q} * S_{\bar{x}}=2.04 * 1.85=3.78 \%$, where $t_{q}$ is correction coefficient 2.04 (Rabinovich, 2013) and $S_{\bar{x}}$ is the standard deviation of the measured result. Multiple uncertainty is $\zeta_{0.95}=$ $3.96 \%+3.78 \%=7.74 \%$. Table 2 shows measurement uncertainties for solar flux, surface temperature measurements, velocity and operative temperature. 
Table 2. Measurement uncertainty

\begin{tabular}{c|cccccc}
\hline & $\vartheta_{o}$ & $\mathrm{k}_{\mathrm{a}}$ & $\vartheta_{i}$ & $\mathrm{t}_{\mathrm{q}}$ & $\mathrm{Sx}$ & $\zeta_{0.95}[\%]$ \\
\hline Solar flux & 3.5 & 1.12 & 1 & 2.04 & 1.73 & 7.61 \\
Surface temperature & 2 & 1.12 & 2.5 & 2.04 & 1.92 & 7.5 \\
Heat flux & 2.5 & 1.12 & 2.5 & 2.04 & 1.85 & 7.74 \\
Velocity & 1 & 1.12 & 1 & 2.04 & 2 & 5.67 \\
Operative temperature & 1 & 1.12 & 2 & 2.04 & 1.6 & 5.77 \\
\hline
\end{tabular}

\subsection{Total floor cooling capacity calculation}

The cooling capacity for the case when the window was open and part of the floor was exposed to the direct solar was calculated in two parts. The first part is the area exposed to the sun $(\sim 6$ $\left.\mathrm{m}^{2}\right)$. the second part is the area of the floor that is not exposed to the sun $\left(-54 \mathrm{~m}^{2}\right)$.

\section{Results and Discussion}

\subsection{Solar penetration through the windows}

Results in Figure 2a show distribution of global solar irradiance that reached the horizontal roof surface on chamber $3 \mathrm{~B}$ for $25^{\text {th }}$ and $30^{\text {th }}$ April and $2^{\text {nd }}$ May 2016. The right photo in Figure 1a shows how the sunlight penetrated into the indoor environment and the part of the floor directly irradiated by the sunlight. Results presented in Figure 2 show that global solar irradiance was similar for these days. We measured the intensity of the solar radiation passing through the double-glazed window in the vertical plane by mounting pyranometer immediately inside the window glass. Figure $2 b$ depicts the solar intensity profile after the window. Results in Figure $2 b$ are from the same days and show that solar radiation on the horizontal surface on the roof reaches up to $1000 \mathrm{~W} / \mathrm{m}^{2}$. Solar irradiance in the vertical plane after the window reached a peak of approximately $100 \mathrm{~W} / \mathrm{m}^{2}$. Profiles depicted in Figures $2 \mathrm{a}$ and $\mathrm{b}$ show the sudden drop at one point due to cloud shading. The similarity between solar profiles depicted in Figures 3a allows us to compare the radiant floor surface heat fluxes for different chilled water supply temperature used on those respective days.
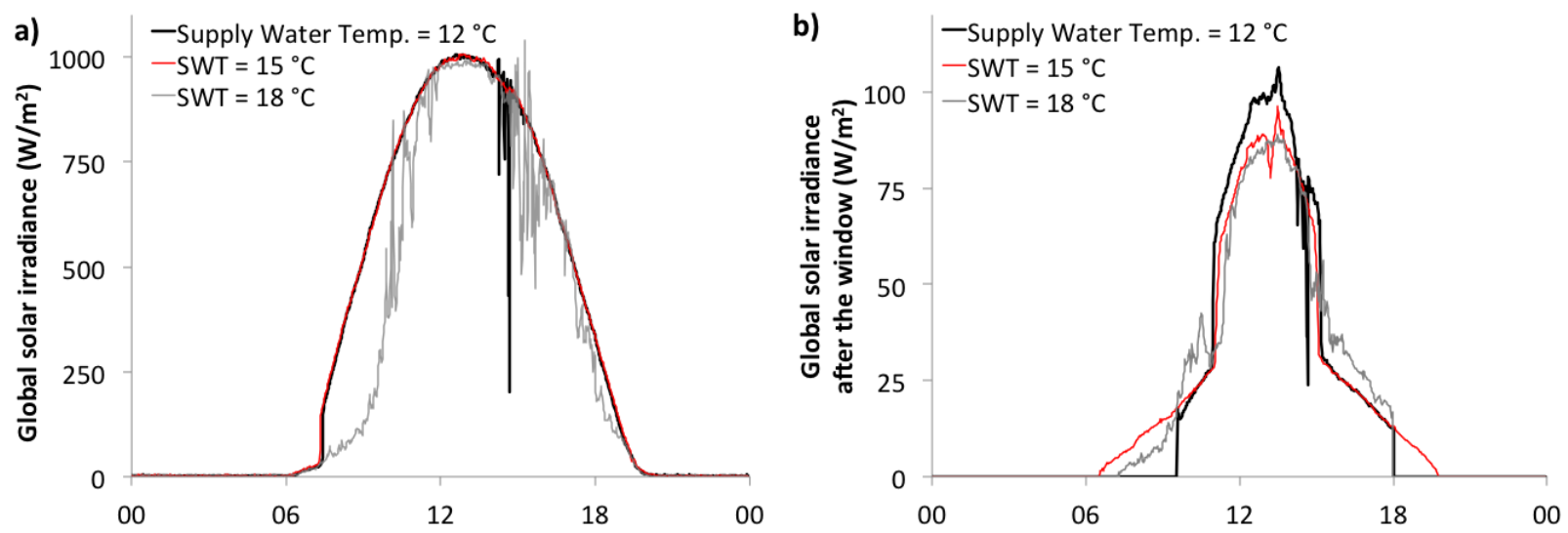

Figure 2. (a) Global horizontal solar irradiance measured on the roof of the FLEXLAB and (b) global vertical solar irradiance immediately after the window glass for three typical days (April $25^{\text {th }}$, April $30^{\text {th }}$ 
and May $\left.2^{\text {nd }}\right)$ for chilled water supply temperatures of 12,15 and $18^{\circ} \mathrm{C}$ respectively.

\subsection{Impact of solar radiation on cooling capacity}

Results in Figure 3a depict an example of floor surface heat flux when there is direct solar radiation. Results show that during the experiments, the cooling capacity of the floor can increase to up to $100 \mathrm{~W} / \mathrm{m}^{2}$ for a period of four hours. For the remaining time of the day the heat flux was between 25 and $39 \mathrm{~W} / \mathrm{m}^{2}$. These results suggest that the cooling capacity for the part of the floor that is exposed to direct solar radiation can increase significantly. Results show that heat flux readings had peaks and valleys at different times. Window frame or cloud shading caused the peaks and valleys. The difference between results depicted in Figure $3 \mathrm{a}$ and reported in the literature can be mainly attributed to the window properties and specific solar angle.

Figure $3 \mathrm{~b}$ shows the boxplots of the surface heat fluxes for one large and four small heat flux sensors. The results show that the surface heat fluxes of 5 sensors are very close (medians between 33 and $40 \mathrm{~W} / \mathrm{m}^{2}$ ). Differences can be attributed to solar shading cause by window frame and clouds, different relative position on the floor in relation to the supply PEX tube and heterogeneity of the heat flux through the floor concrete. Instead of showing complex figures (e.g., Figure $3 \mathrm{a}$ and $\mathrm{b}$ ) and readings from a large number of heat flux sensors, we decided to focus our analysis on the measurements with 3 large heat flux sensors distributed on the radiant floor.
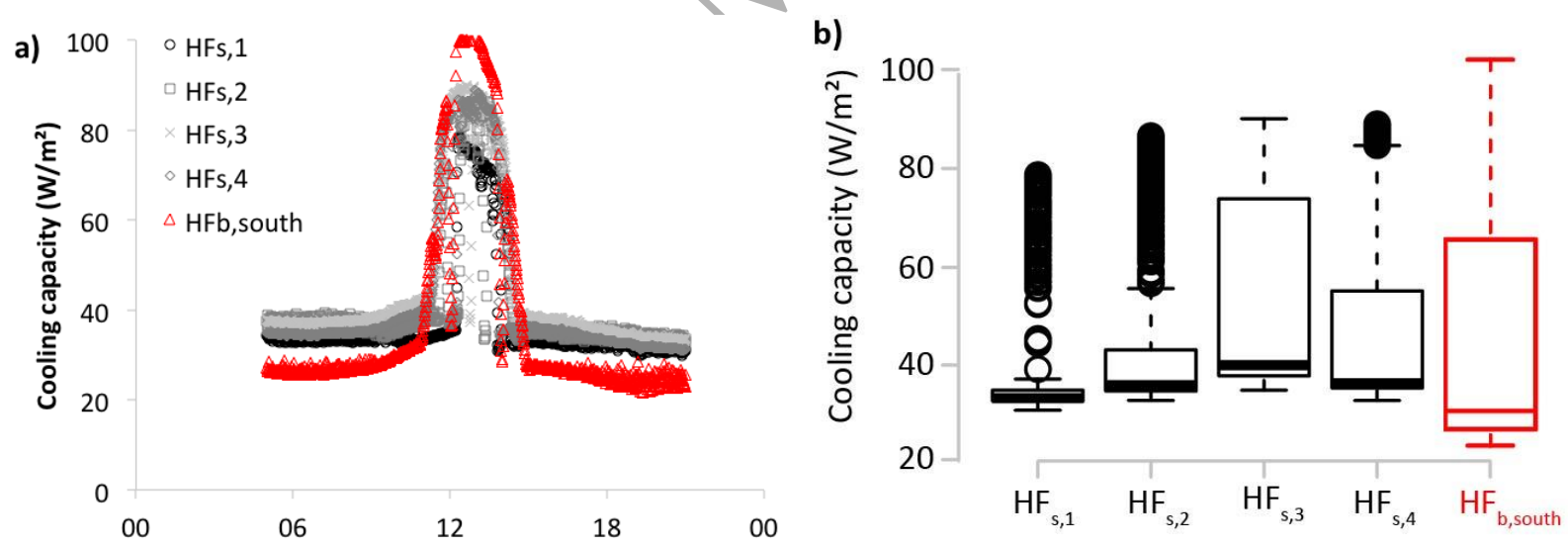

Figure 3: Surface heat flux measured on the sensors exposed to direct solar radiation as (a) timeseries and (b) boxplots. $\mathrm{HF}_{s, 1}, \mathrm{HF}_{\mathrm{s}, 2}, \mathrm{HF}_{\mathrm{s}, 3}, \mathrm{HF}_{\mathrm{s}, 4}$ represent row of small heat flux sensors next to the window. $H F_{b, s o u t h} i s$ the large heat flux sensor placed next to the window. Measurement took place on May $5^{\text {th }}$, 2016.

\subsection{Impact of supply water temperature on cooling capacity}

Figures $4 \mathrm{a}, \mathrm{b}$ and $\mathrm{c}$ compare the cooling capacity measured with large heat flux sensors as a function of supply water temperature. The surface heat flux of the radiant cooling slab exposed 
to the sun reaches a peak heat flux around noon (the difference between solar time and clock time is less than $10 \mathrm{~min}$ ). This coincides with the peak solar time, indicating that there is no time delay between these two phenomena, as one would expect. For the areas that are not exposed to direct solar radiation, the heat fluxes do not change much throughout the day because the total thermal loads remain fairly steady. Results in Figure 5a show average surface heat flux as a function of the chilled water supply temperature. Averaging depicted in Figure 5a was done using a floor area weighted average of sun exposed and unexposed regions. When increasing the supply water temperature from 12 to $18{ }^{\circ} \mathrm{C}$ (Figure $4 \mathrm{a}, \mathrm{b}$ and c), the heat flux in the middle of the chamber (the region that is not directly affected by solar irradiance), decreased from $40 \mathrm{~W} / \mathrm{m}^{2}$ to below $30 \mathrm{~W} / \mathrm{m}^{2}$ (a $25 \%$ reduction). In the north region of the floor, the heat flux marginally changed with changes to supply water temperature. In the floor regions affected by solar, the peak heat flux decreased from $115 \mathrm{~W} / \mathrm{m}^{2}$ to $95 \mathrm{~W} / \mathrm{m}^{2}$ or $18 \%$ (Figure $4 \mathrm{a}, \mathrm{b}$ and $\mathrm{c}$ ), with increasing supply water temperature. Results in Figure 4a, b and c show that average floor heat flux (surface cooling capacity) increased with the decrease of chilled water supply temperature, as expected. A similar trend can be observed in Figure 5a. 

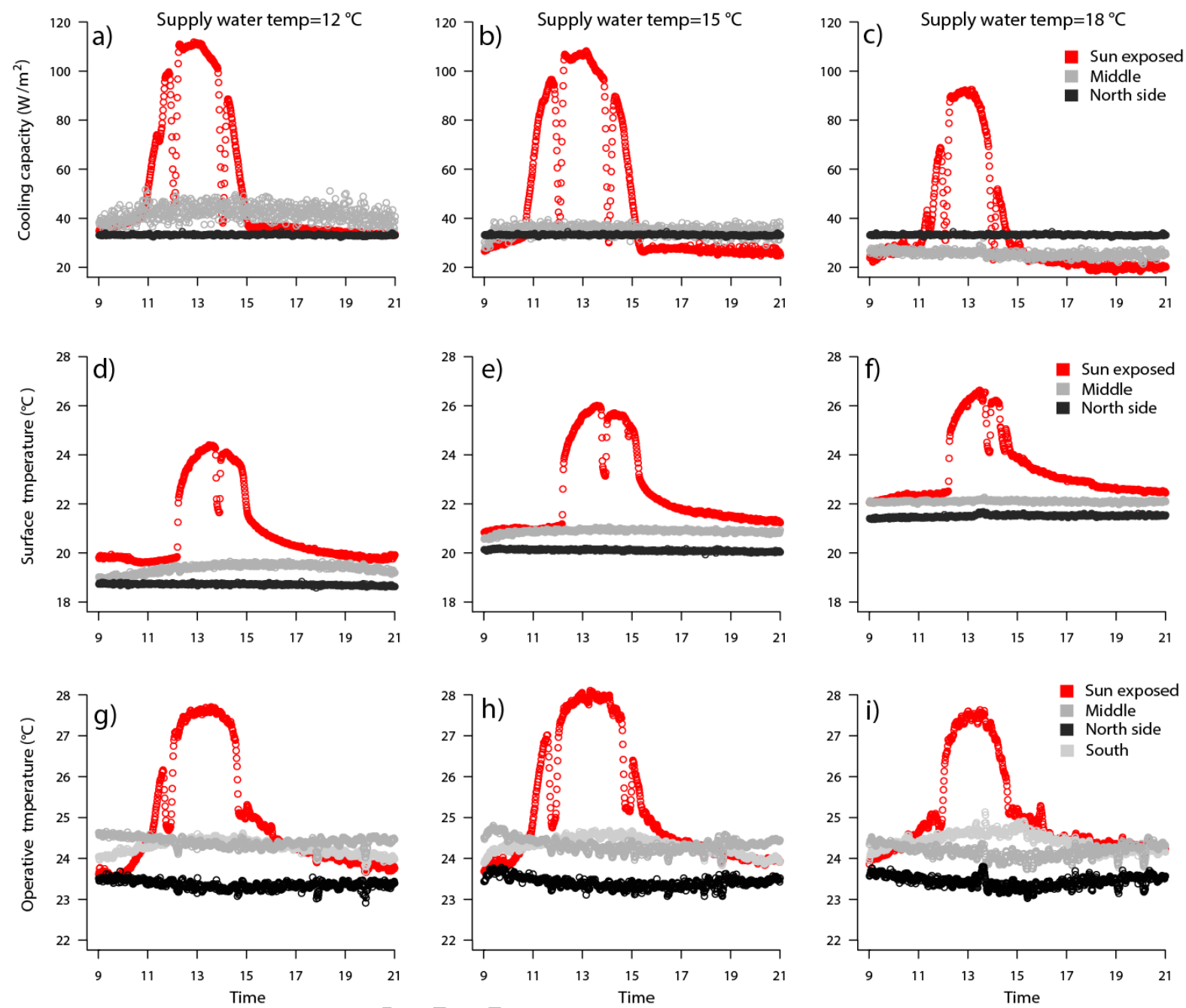

Figure 4. Figure 4a, Figure 4b and Figure 4c: Daily surface cooling capacity for different areas of the chamber for water supply temperature of 12, 15 and $18^{\circ} \mathrm{C}$; Figure $4 d$, Figure 4 e and Figure $4 f$ : Daily floor surface temperature for different areas of the chamber for water supply temperature of 12,15 and $18^{\circ} \mathrm{C}$; Figure $4 \mathrm{~g}$, Figure $4 \mathrm{~h}$ and Figure $4 i$ : Daily operative temperature for different areas of the chamber for water supply temperature of 12,15 , and $18^{\circ} \mathrm{C}$.

Figures $4 \mathrm{~d}, 4 \mathrm{e}$ and $4 \mathrm{f}$ show the radiant floor surface temperatures. Figure $5 \mathrm{~b}$ shows the areaweighted surface temperatures. Results in Figure $4 \mathrm{~d}, 4 \mathrm{e}$ and $4 \mathrm{f}$ for one water supply temperature (e.g., $15^{\circ} \mathrm{C}$ ) show that two distinct surface temperature regions exist. The first region, that is affected by solar has a peak floor surface temperature of $26^{\circ} \mathrm{C}$, and the second region, unaffected by solar, has floor surface temperature between 20 and $21^{\circ} \mathrm{C}$. This is an important result because we can clearly observe that although floor cooling capacity increased (Figure 4a, $4 \mathrm{~b}, 4 \mathrm{c})$, the floor area affected by the direct solar has a higher temperature compared to the area unaffected by the direct solar radiation. 
Results in Figure 4d, e and f also show that floor surface temperature can increase up to $1.5^{\circ} \mathrm{C}$ when supply water temperature was increased from 12 to $18{ }^{\circ} \mathrm{C}$ in the areas directly exposed to solar. In the regions without direct solar, the surface temperature difference was $2.5^{\circ} \mathrm{C}$. Results in Figure 4 show that floor surface temperature is less sensitive to the supply chilled water temperature change in the regions affected by direct solar irradiance. Similarly, weighted average results in Figure $5 \mathrm{~b}$ show that surface temperature increases from $20^{\circ} \mathrm{C}$ to $22{ }^{\circ} \mathrm{C}$ for when chilled water supply temperature increased from 12 to $18{ }^{\circ} \mathrm{C}$.

Results in Figure 4d, e and f, and Figure 5b suggest that separate hydronic loop zoning with the lower chilled water supply temperature in the sun-affected region can reduce surface temperature. For a $6{ }^{\circ} \mathrm{C}$ change in the supply chilled water temperature, slab surface temperature showed a variation of up to $2.5^{\circ} \mathrm{C}$ or up to $2{ }^{\circ} \mathrm{C}$ when considering the area weighted calculation. Results in Figure 4g. 4h and 4i show that reduction of supply water temperature for $6{ }^{\circ} \mathrm{C} \mathrm{did} \mathrm{not}$ impact operative temperature in the sun-exposed region.

Results depicted in Figure 4g, h and i show operative temperature readings for one sensor exposed to the direct solar and three sensors that were not. The operative temperature in the solar affected region can reach $28{ }^{\circ} \mathrm{C}$ compared to an operative temperature set point of $24{ }^{\circ} \mathrm{C}$. Operative temperature sensors that were not affected by the direct solar measured operative temperature $24 \pm 0.5^{\circ} \mathrm{C}$. Area weighted calculations are depicted in Figure $5 \mathrm{c}$ and they show large distribution of temperatures but very similar medians for all supply water temperatures.
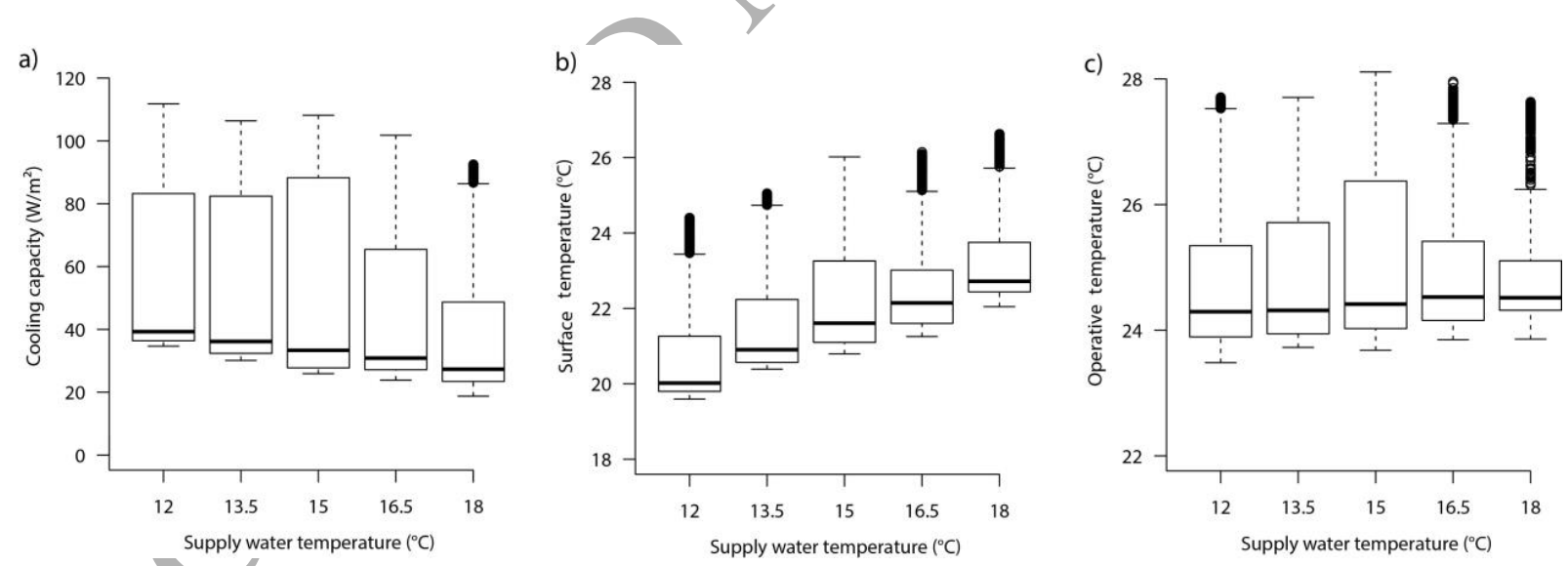

Figure 5. (a) surface cooling capacity (heat flux) of the radiant floor, (b) surface temperature and (c) operative temperature as a function of the chilled water supply temperature.

\subsection{Combined impact of solar radiation and supply water temperature on cooling capacity}

Figure 6 presents cooling capacity as a function of reference temperature difference $\left(\Delta T_{h}\right) . \Delta T_{h}$ expresses the combined influence of cooling system characteristics as a function of supply, $T_{w i}$, and return, $T_{w o}$, chilled water temperatures and room operative temperature, $T_{o p}$, as shown in the 
equation (1). $\Delta T_{h}$ is used during the design to determine radiant floor cooling capacity (ISO 2012).

$$
\Delta T_{h}=\frac{T_{w i}-T_{w o}}{\ln \frac{T_{w i}-T_{o p}}{T_{w o}-T_{o p}}}
$$

Results in Figure 6c and d compare the radiant floor cooling capacity for the same floor area with the window blocked and open, allowing floor exposure to direct solar. Results show that the cooling capacity of the areas close to the window can increase from around $20 \mathrm{~W} / \mathrm{m}^{2}$ (window blocked) to $110 \mathrm{~W} / \mathrm{m}^{2}$ (window open, exposed to the direct solar). Results show that with the increase of $\Delta T_{h}$, the floor cooling capacity will increase. Similar results can be observed in Figure 6 where surface cooling capacity is given as a function of chilled water supply temperature. The trend observed in Figure $6 \mathrm{c}$ and $6 \mathrm{~d}$ can be attributed to the chilled water supply temperature reduction that will reduce the floor surface temperature. Comparison of cases with and without direct solar shows that when the floor is exposed to direct solar, the solar radiation has the dominant impact on cooling capacity. 

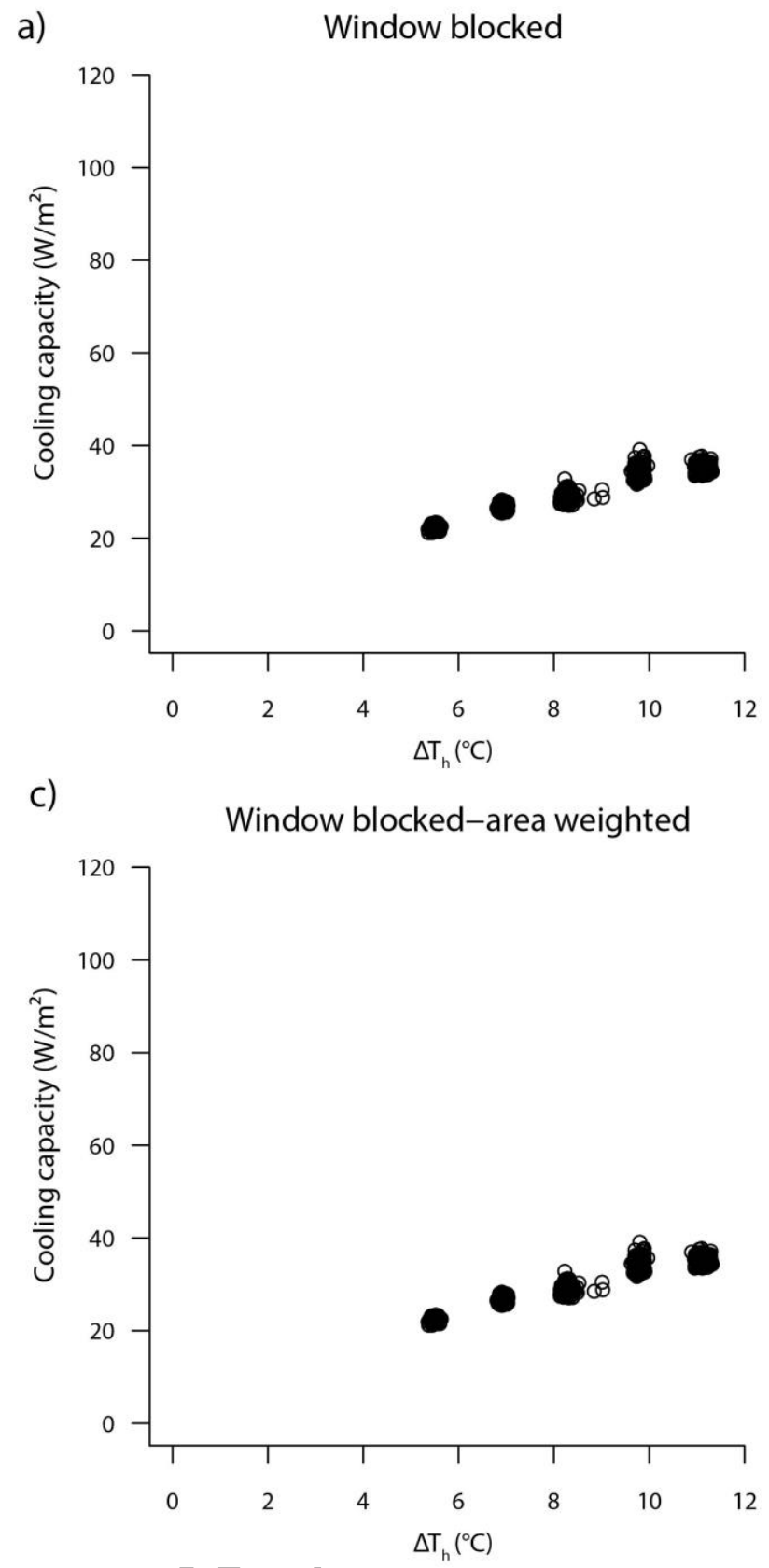

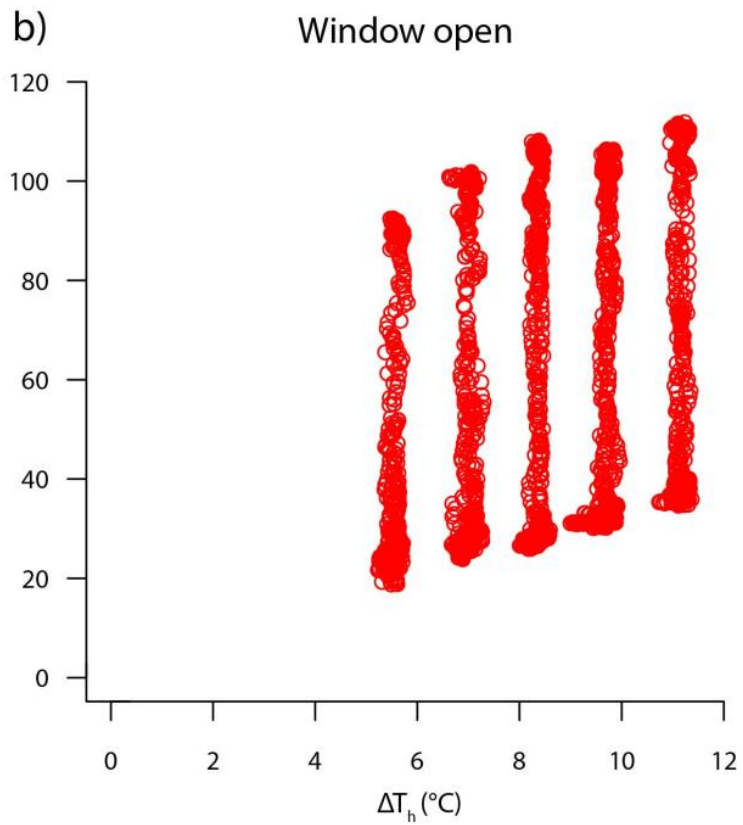

d)

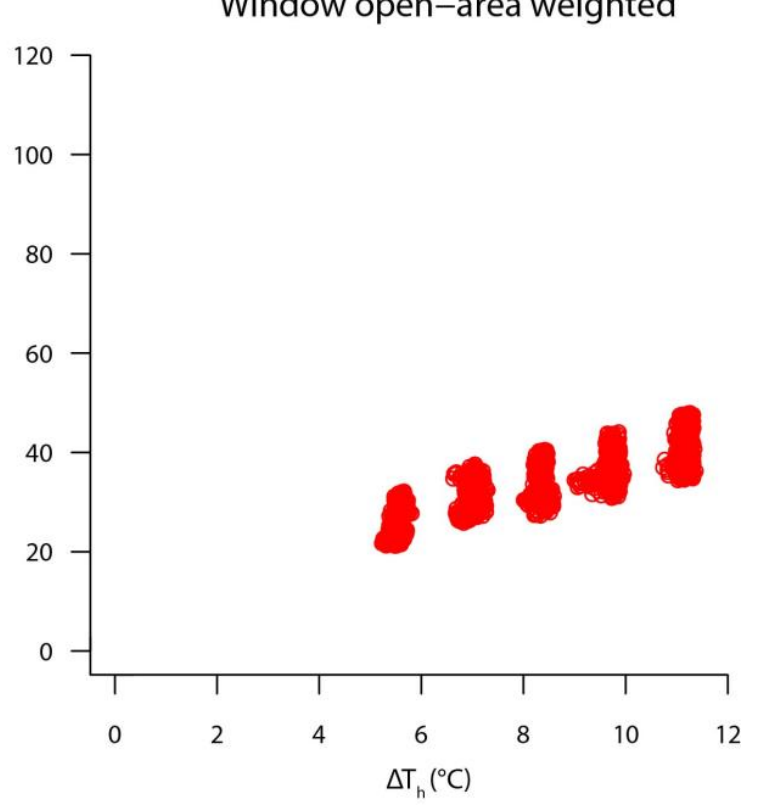

Figure 6. Figure 6a and Figure 6b: Surface cooling capacity for areas close to the window (a) window blocked; (b) window open. Notes: there are 5 cases with supply water temperature of 18, 16.5, 15, 13.5 and $12^{\circ} \mathrm{C}$; (a) uses 3-h data points; (b) uses 9-h data, from 9:00 - 18:00; Figure 6c and Figure 6d: Area weighted surface cooling capacity for: (a) window blocked; (b) window open; Notes: there are 5 cases with supply water temperature of $18,16.5,15,13.5$ and $12{ }^{\circ} \mathrm{C}$. (c) uses 3-h data points; (d) uses 9- $h$ data, from 9:00-18:00.

When we averaged the results for the whole floor area they show (Figure 6c and 6d) that cooling capacity increases with an increase of $\Delta T_{h}$, but compared to the case with the blocked window, 
the increase in cooling capacity is marginal. This is due to the small overall area that is exposed to the sun in our experimental test configuration (depicted in Figure 1), a factor that was outside of our control due to the geometry of the test chamber.

\subsection{Impact of ceiling fan and carpet on the radiant slab cooling capacity}

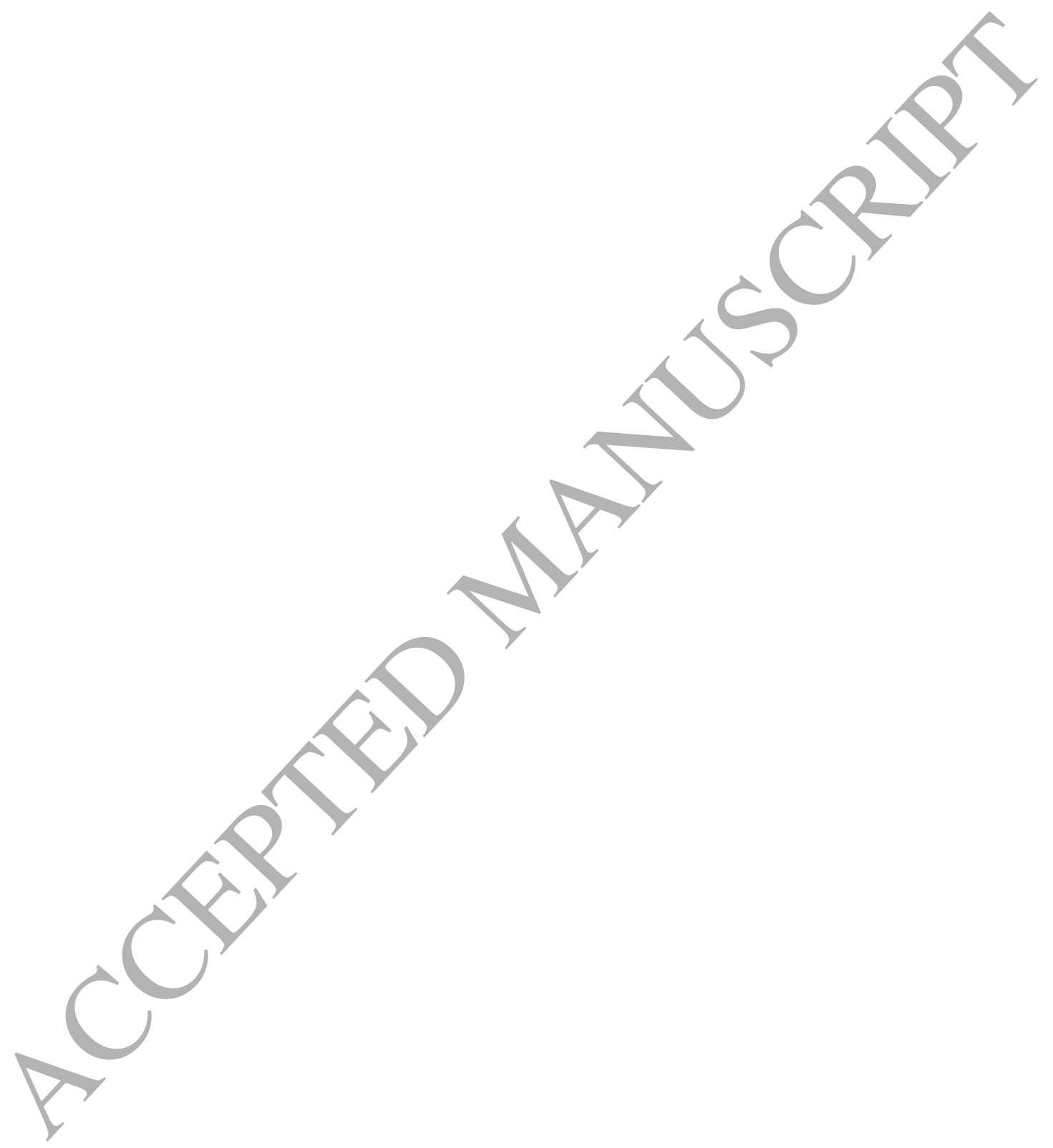




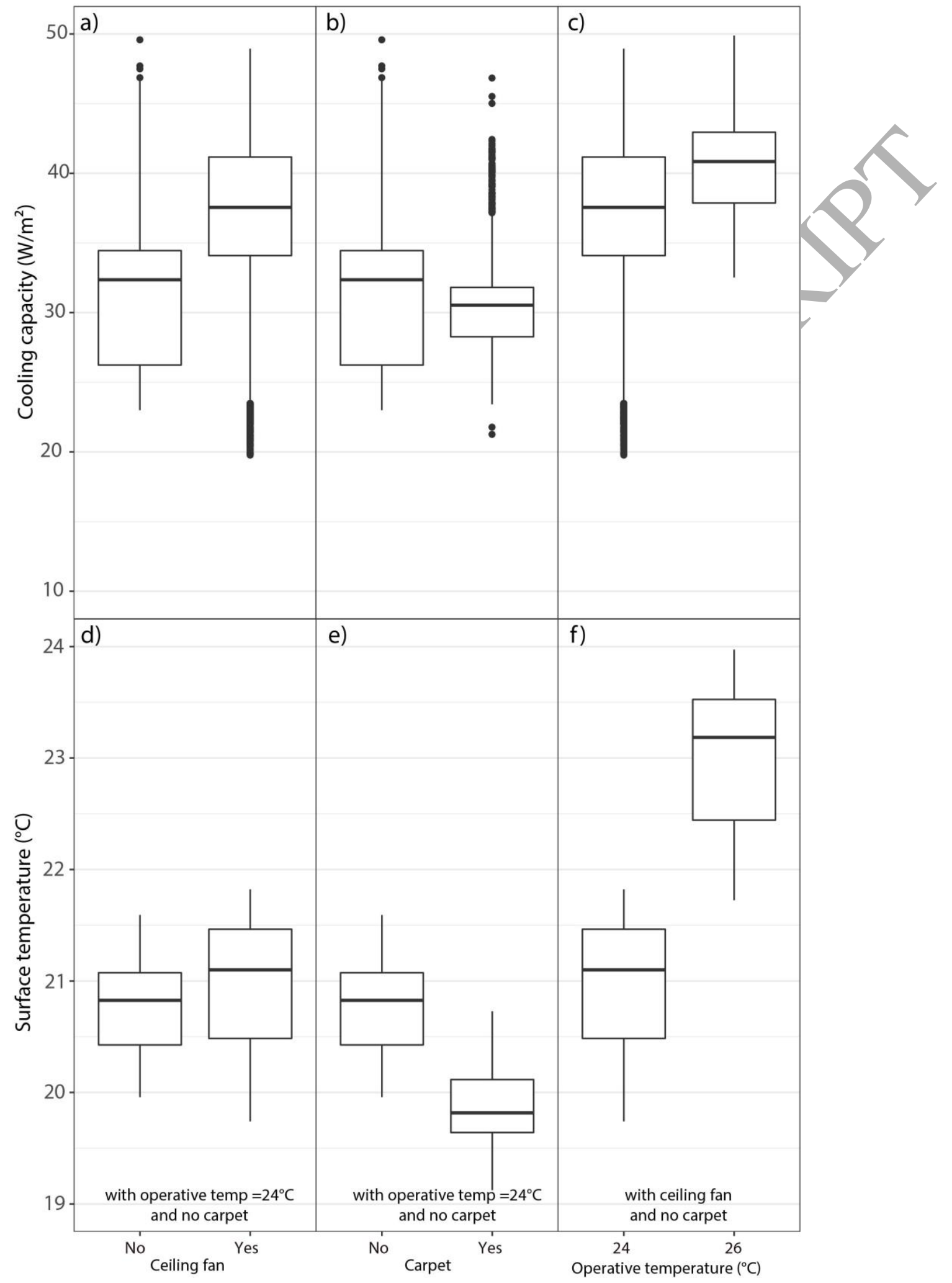


Figure 7. Radiant floor cooling capacity for bare slab, use of fan at $T_{o p}=24^{\circ} \mathrm{C}$ and $T_{o p}=26^{\circ} \mathrm{C}$ and when thin carpet tiles were placed on the top of the radiant slab. Floor surface temperature is depicted in Figure $7 d, 7 e$ and $7 e$ for bare slab, use of fans at $T_{o p}=24^{\circ} \mathrm{C}$ and $T_{o p}=26^{\circ} \mathrm{C}$ and carpet on a slab. In all cases chilled water supplied to the floor was $15^{\circ} \mathrm{C}$. Figure 2 shows the location of the surface temperature sensor.

Results presented in Figure 7 show the impact of ceiling fan and carpet tiles on the radiant slab cooling capacity. During the experiments, we blocked the windows to avoid measurement uncertainty caused by variation of solar irradiation. We positioned floor surface heat flux sensors (measured cooling capacity) between ceiling fans. When we conducted experiments with the ceiling fan, the performance was evaluated at operative temperatures of $24{ }^{\circ} \mathrm{C}$ and $26^{\circ} \mathrm{C}$. A higher room operative temperature of $26^{\circ} \mathrm{C}$ was added, in addition to the $24{ }^{\circ} \mathrm{C}$ used in the other experiments, because most likely a higher spatial operative temperature will be used when air movement is increased.

Results in Figure 7 a show that use of a ceiling fan can increase radiant slab cooling capacity by approximately $16 \%$, from $32.4 \mathrm{~W} / \mathrm{m}^{2}$ in the baseline operation at the operative temperature of 24 ${ }^{\circ} \mathrm{C}$ to $37.6 \mathrm{~W} / \mathrm{m}^{2}$. Radiant slab cooling capacity can be increased up to $41 \mathrm{~W} / \mathrm{m}^{2}$, or approximately $26 \%$, when baseline operation was compared to ceiling fan elevated air movement at an operative temperature of $26^{\circ} \mathrm{C}$ (Figure $7 \mathrm{c}$ ). In both cases, radiant floor cooling capacity increased due to the increase in convective heat transfer coefficient on the floor. In the case of operative temperature of $26^{\circ} \mathrm{C}$, the temperature difference between the floor and the air was increased (Figure 7f) and that caused a larger increase in cooling capacity.

When comparing surface temperatures (Figure 7d) for the bare slab operated at $\mathrm{T}_{\mathrm{op}}=24^{\circ} \mathrm{C}$, the surface temperature only increased by less than $0.3{ }^{\circ} \mathrm{C}$ when the ceiling fan was turned on, for the chilled water supply temperature of $15^{\circ} \mathrm{C}$. Ambient air temperature in the chamber in both cases was $24.4^{\circ} \mathrm{C}$, suggesting that temperature difference between the air and the floor surface was $\sim 3{ }^{\circ} \mathrm{C}$. When $\mathrm{T}_{\mathrm{op}}$ was increased to $26{ }^{\circ} \mathrm{C}$ floor surface temperature was increased by $\sim 2{ }^{\circ} \mathrm{C}$ while maintaining the same floor to ambient air temperature difference.

Figure $7 \mathrm{~b}$ shows that radiant floor cooling capacity is marginally reduced $(\sim 5 \%)$ with typical thin carpet tile used in the USA offices. All the surface temperatures presented in Figure $7 \mathrm{~d}, 7 \mathrm{e}$ and $7 \mathrm{f}$ refer to the concrete slab surface and temperatures were obtained for the same chilled water supply temperature. Differences that can be observed are caused by changes in ambient temperature $\left(24.4{ }^{\circ} \mathrm{C}\right.$ for $\mathrm{T}_{\mathrm{op}}=24^{\circ} \mathrm{C}$ and 26.5 for $\left.\mathrm{T}_{\mathrm{op}}=26^{\circ} \mathrm{C}\right)$ and thermal resistance of the carpet. Results suggest that thermal resistance created by the carpet causes concrete slab surface temperature (surface immediately below a carpet) to be lower than in other cases examined in this study. When carpet was used (Figure 7e) concrete slab surface temperature was lower then in other examined case $\left(\sim 5^{\circ} \mathrm{C}\right.$ higher then supply water temperature). 


\section{Discussion and Practical Implications}

Floor area with direct solar exposure will have higher surface temperatures, an effect that depends on the intensity of the solar radiation reaching the floor. From the thermal comfort perspective if the solar exposed area is large enough, the air temperature should be reduced to maintain comfortable conditions. This is especially true in cases where the occupant will also be exposed to direct solar radiation, an effect that can be quantified using the SolarCal component of Standard 55 (ASHRAE Standard 55). From the engineering perspective the main design consideration is that the envelope should be appropriately shaded from solar radiation.

Nevertheless, in some cases, the architectural expression prevents façade shading from being implemented (an example is Anaheim Regional Transportation Intermodal Center building).

Results above have three important design implications when envelope shading cannot be implemented: depth of the in-slab sensors used for control and monitoring, spatial distribution of in-slab temperature sensors, maintaining comfort conditions and coupling radiant cooling with an additional system. This design consideration will be important for spaces that have large glazing area, transparent roofs and permanent occupancy.

The depth of the in-slab temperature sensors used for control and monitoring is important. Depending on the position of the sensors we can have a different reading of the floor temperature that is used for the control (combination of slab and air temperature). In the case of carpet, the air temperature was $24.6{ }^{\circ} \mathrm{C}$ and concrete slab surface temperature (below a carpet tile) was $19.8{ }^{\circ} \mathrm{C}$. When simple averaging of air and concrete slab surface temperature is used, this would yield combined temperature of $22.2{ }^{\circ} \mathrm{C}$ which is substantially different then operative temperature of $24.1^{\circ} \mathrm{C}$ measured in the space. This difference can be attributed to the difference between concrete slab surface temperature and temperature of the carpet surface. Depending on the carpet resistance concrete slab surface temperature (below a carpet tile) can be even lower while carpet surface temperature might be higher resulting in an even large difference between real operative temperature in the space compared to combined air and slab surface temperature averaging methodology. This correlation requires further study, however it points out the importance of operative temperature use instead of the air and surface temperature averaging for buildings where carpets are used in combination with the floor cooling.

The spatial distribution of in-slab temperature sensors is the second important design consideration. The cooling floor will contain regions with direct exposure to solar and regions that are not exposed, hence in order to provide comfort conditions through the whole indoor environment both floor regions needs to be effectively detected. Different approaches can be chosen for detection and some will include floor surface temperature monitoring, operative temperature monitoring or return water temperature monitoring. Only properly distributed 
sensors will provide the right information for the building management system to maintain comfort conditions in the indoor environment.

Since occupant thermal experience correlated with operative temperature the third design consideration is maintain operative temperature. One of the possible solutions would be that zoning of accompanying air system has to include consideration of the floor area exposed to the direct solar (Nall, 2013). With this particular strategy cooling slab surface temperature increase due to direct solar can be compensated with the air system. This approach would require reasonably accurate prediction of the areas of the floor that will be exposed to the direct solar. Another possible solution is specially zone floor hydronic system in the areas exposed to the direct solar. Results from this study, show that reduction of supply water temperature for $6{ }^{\circ} \mathrm{C}$ changed slab surface for $2{ }^{\circ} \mathrm{C}$, but did not have significant impact on operative temperature in the sun-exposed region. These results suggest that separate hydronic loop zoning with the lower chilled water supply temperature in the sun-affected region can reduce surface temperature, but that approach might not be the most effective way of controlling slab surface temperature in the solar exposed zones. Considering effectiveness in surface temperature change and additional complexity required to create a separate hydronic loop, based on the results from this study, we do not recommend this design solution. We recognize limitation of this observation because it was done only for a single slab thickness, one PEX configuration and single chilled water flow rate. Based on our observation the most effective way to respond to direct solar could be to increase air speed locally. Since use of the ceiling fans increased floor temperature between 0.3 ${ }^{\circ} \mathrm{C}$ and $2{ }^{\circ} \mathrm{C}$ this suggests that use of ceiling fans increases floor capacity with a marginal increase of the surface temperature This result further suggests that combining radiant floor with elevated air movement induced by ceiling fans represents a very good combination from the thermal comfort perspective because radiant exchange with cold floor surface is almost unaffected with a gain of the enhanced convective exchange. With the possibility to increase capacity by $20 \%$, the combination of radiant floor and ceiling fans has the potential to be an important low energy cooling solution. Radiant systems and especially TABS have the potential to utilize low lift chillers with a higher coefficient of performance (Armstrong et al., 2009a) or direct or indirect evaporative cooling (Caliskan et al., 2011). In addition, elevated air movement is one of the most energy efficient strategies for providing thermal comfort to occupants, particularly under warm conditions (Schiavon and Melikov, 2008; Hoyt et al., 2015; Sekhar, 1995; Duarte et al., 2015).

\section{Limitations}

We conducted experiments from April until May with a small floor area close to the window exposed to direct solar radiation. Another limitation was imposed by the geometry of the chamber. The chamber had only one window facing south, and the floor area was rectangular which resulted in a small direct solar floor exposure. Another limitation is that experiments were conducted with only one hydronic loop configuration and only one slab thickness. We operated 
the chamber based on the operative temperature sensors that created a mismatch between the control strategy used in the experiment vs those commonly used for these systems in practice.

\section{Conclusions}

This paper describes the results of a controlled laboratory study to investigate impact of direct solar, use of ceiling fans and carpet tiles on the cooling capacity of the radiant floor. To our best knowledge this is the first fully controlled experimental study. Based on the results following conclusions can be derived.

Results for one water supply temperature (e.g., $15^{\circ} \mathrm{C}$ ) show that two distinct cooling capacity and surface temperature regions exist. Cooling capacity of chilled radiant floor can be increased from $30 \mathrm{~W} / \mathrm{m}^{2}$ up to $110 \mathrm{~W} / \mathrm{m}^{2}$ with direct solar radiation based on the results of this experiment. Changes of the chilled water supply temperature from 12 to $18{ }^{\circ} \mathrm{C}$ led to decreased cooling capacity from $\sim 110 \mathrm{~W} / \mathrm{m}^{2}$ to $\sim 95 \mathrm{~W} / \mathrm{m}^{2}$. In the middle region of the test room, the cooling capacity decreased from $\sim 40 \mathrm{~W} / \mathrm{m}^{2}$ to below $30 \mathrm{~W} / \mathrm{m}^{2}$. The region close to the window that was affected by direct solar had a peak floor surface temperature of $26^{\circ} \mathrm{C}$, while the unaffected region away from the window had floor surface temperatures between 20 and $21^{\circ} \mathrm{C}$. Although floor cooling capacity increased, the floor area affected by the direct solar has a higher temperature compared to the area unaffected by the direct solar radiation. This has impact on thermal comfort of the occupants and requires consideration during positioning and selection of the slab temperature sensors.

Results also show that floor surface temperature can increase up to $1.5^{\circ} \mathrm{C}$ when supply water temperature was increased from 12 to $18{ }^{\circ} \mathrm{C}$ in the areas directly exposed to solar, while in the regions without direct solar the surface temperature increase was $2.5^{\circ} \mathrm{C}$. Results show that reduction of supply water temperature by $6^{\circ} \mathrm{C}$ did not impact operative temperature in the sunexposed region. Having a localized lower temperature may be a challenge from the design point of view. Considering effectiveness in surface temperature change and additional complexity required to create a separate hydronic loop, based on the results from this study, we do not recommend this design solution.

Ceiling fans can increase radiant slab cooling capacity by approximately $16 \%$ at the same operative temperature - from $32 \mathrm{~W} / \mathrm{m}^{2}$ in the baseline operation at the operative temperature of $24{ }^{\circ} \mathrm{C}$ up to $36 \mathrm{~W} / \mathrm{m}^{2}$. Radiant slab cooling capacity can be further increased up to $42 \mathrm{~W} / \mathrm{m}^{2}$, or by approximately $26 \%$, when the operative temperature is increased to $26^{\circ} \mathrm{C}$ to account for the effect of increased air movement on thermal comfort. The combination of radiant floor and ceiling fans has the potential to be an important low energy cooling solution.

The presence of thin carpet tiles reduced the radiant floor cooling capacity for $\sim 5 \%$. This is a small decrease in the cooling capacity, but it has impact on surface temperature hence it is 
important to know which area of the floor will be covered by the carper because using a slab surface temperature measurement for control will be affected.

\section{References}

Armstrong, P.R., Jiang, W., Winiarski, D., Katipamula, S., Norford, L.K., 2009. Efficient low-lift cooling with radiant distribution, thermal storage, and variable-speed chiller controls-Part II. Annual use and energy savings. HVACR Res. 15, 402-432.

ASHRAE 55-2017 [WWW Document], n.d. URL https://www.techstreet.com/standards/ashrae-552017?gclid=CjwKCAjw64bPBRApEiwAJhG-fhFCb34pUWhN1jAQq6Xwuphj4DSnYuPtKBTo3wkOSo5gne2_0fbOBoCYWQQAvD_BwE\&sid=goog\&product_id=1994974 (accessed 10.14.17).

Babiak, J., Olesen, B.W. and Petráš, D., 2007. Low temperature heating and high temperature cooling (Vol. 7). Forssa, Finland: Forssan Kirjapaino Oy

Caliskan, H., Hepbasli, A., Dincer, I., Maisotsenko, V., 2011. Thermodynamic performance assessment of a novel air cooling cycle: Maisotsenko cycle. Int. J. Refrig. 34, 980-990. doi:10.1016/j.ijrefrig.2011.02.001

Causone, F., Corgnati, S.P., Filippi, M., Olesen, B.W., 2010. Solar radiation and cooling load calculation for radiant systems: Definition and evaluation of the Direct Solar Load. Energy Build. 42, 305314. doi:10.1016/j.enbuild.2009.09.008

De Carli, M., Olesen, B.W., Zarrella, A. and Zecchin, R., 2007. People's clothing behaviour according to external weather and indoor environment. Building and Environment, 42(12), pp.3965-3973.

Duarte, C., Raftery, P., Schiavon, S., 2016. SinBerBEST Technology Energy Assessment Report. Build. Effic. Sustain. Trop.

Fabrizio, E., Corgnati, S.P., Causone, F., Filippi, M., 2012. Numerical comparison between energy and comfort performances of radiant heating and cooling systems versus air systems. HVACR Res. 18, 692-708. doi: 10.1080/10789669.2011.578700

Feng, J. (Dove), Bauman, F., Schiavon, S., 2014. Experimental comparison of zone cooling load between radiant and air systems. Energy Build. 84, 152-159. doi:10.1016/j.enbuild.2014.07.080

Feng, J. (Dove), Schiavon, S., Bauman, F., 2016. New method for the design of radiant floor cooling systems with solar radiation. Energy Build. 125, 9-18. doi:10.1016/j.enbuild.2016.04.048

Feng, J. (Dove), Schiavon, S., Bauman, F., 2013. Cooling load differences between radiant and air systems. Energy Build. 65, 310-321. doi:10.1016/j.enbuild.2013.06.009

Feustel, H.E., Stetiu, C., 1995. Hydronic radiant cooling — preliminary assessment. Energy Build. 22, 193-205. doi:10.1016/0378-7788(95)00922-K 
Gao, Y., Zhang, H., Arens, E., Present, E., Ning, B., Zhai, Y., Pantelic, J., Luo, M., Zhao, L., Raftery, P., Liu, S., 2017. Ceiling fan air speeds around desks and office partitions. Build. Environ. 124, 412440. doi:10.1016/j.buildenv.2017.08.029

Gwerder, M., Lehmann, B., Tödtli, J., Dorer, V., Renggli, F., 2008. Control of thermally-activated building systems (TABS). Appl. Energy 85, 565-581. doi:10.1016/j.apenergy.2007.08.001

Hoyt, T., Arens, E., Zhang, H., 2015. Extending air temperature setpoints: Simulated energy savings and design considerations for new and retrofit buildings. Build. Environ, Interactions between human and building environment 88, 89-96. doi:10.1016/j.buildenv.2014.09.010

ISO 7726:1998 - Ergonomics of the thermal environment -- Instruments for measuring physical quantities [WWW Document], n.d. URL https://www.iso.org/standard/14562.html (accessed 7.24.17).

ISO 7730:2005 - Ergonomics of the thermal environment -- Analytical determination and interpretation of thermal comfort using calculation of the PMV and PPD indices and local thermal comfort criteria [WWW Document], n.d. URL https://www.iso.org/standard/39155.html (accessed 7.24.17).

ISO 11855-2:2012 - Building environment design -- Design, dimensioning, installation and control of embedded radiant heating and cooling systems -- Part 2: Determination of the design heating and cooling capacity [WWW Document], n.d. URL https://www.iso.org/standard/52408.html (accessed 3.18.17a).

ISO 11855-2:2012 - Building environment design - Design, dimensioning, installation and control of embedded radiant heating and cooling systems - Part 2: Determination of the design heating and cooling capacity [WWW Document], n.d. URL https://www.iso.org/standard/52408.html (accessed 7.24.17b).

Karmann, C., Bauman, F.S., Raftery, P., Schiavon, S., Frantz, W.H., Roy, K.P., 2017a. Cooling capacity and acoustic performance of radiant slab systems with free-hanging acoustical clouds. Energy Build. 138, 676-686, doi:10.1016/j.enbuild.2017.01.002

Karmann, C., Schiavon, S., Bauman, F., 2017b. Thermal comfort in buildings using radiant vs. all-air systems: A critical literature review. Build. Environ. 111, 123-131. doi:10.1016/j.buildenv.2016.10.020

Meggers, F, Pantelic, J., Baldini, L., Saber, E.M., Kim, M.K., 2013. Evaluating and adapting low exergy systems with decentralized ventilation for tropical climates. Energy Build. 67, 559-567. doi:10.1016/j.enbuild.2013.08.015

Meggers, F., Ritter, V., Goffin, P., Baetschmann, M., Leibundgut, H., 2012. Low exergy building systems implementation. Energy, 23rd International Conference on Efficiency, Cost, Optimization, Simulation and Environmental Impact of Energy Systems, ECOS 2010 41, 48-55. doi:10.1016/j.energy.2011.07.031

Mumma, S., 2002. Chilled Ceilings in Parallel with Dedicated Outdoor Air Systems: Addressing the Concerns of Condensation, Capacity, and Cost. ASHRAE Transactions 108, 220. 
Nall, D.H., 2013. Thermally active floors. ASHRAE J. 32-46.

Ning, B., Schiavon, S., Bauman, F.S., 2017. A novel classification scheme for design and control of radiant system based on thermal response time. Energy Build. 137, 38-45. doi:10.1016/j.enbuild.2016.12.013

Odyjas, A., Górka, A., 2013. Simulations of floor cooling system capacity. Appl. Therm. Eng. 51, 84-90. doi:10.1016/j.applthermaleng.2012.08.029

Olesen, B.W., 1997. Possibilities and Limitations of Radiant Floor Cooling.

Olesen, B.W., n.d. Using Building Mass to Heat and Cool: Thermo Active Building Systems $\perp$ ashrae.org [WWW Document]. URL https://www.ashrae.org/resources--publications/periodicals/ashraejournal/features/using-building-mass-to-heat-and-cool-thermo-active-building-systems (accessed 4.10.17).

Rabinovich, S.G., 2013. Evaluating Measurement Accuracy. Springer New York, New York, NY. doi:10.1007/978-1-4614-6717-5

Ren, J., Zhu, L., Wang, Y., Wang, C., Xiong, W., 2010. Very low temperature radiant heating/cooling indoor end system for efficient use of renewable energies. Sol. Energy 84, 1072-1083. doi:10.1016/j.solener.2010.03.015

Schiavon, S., Melikov, A.K., 2008. Energy saving and improved comfort by increased air movement. Energy Build. 40, 1954-1960. doi:10.1016/j.enbuild.2008.05.001

Schlueter, A., Rysanek, A., Miller, C., Pantelic, J., Meggers, F., Mast, M., Bruelisauer, M., Chen, K.W., 2016. 3for2: Realizing Spatial, Material, and Energy Savings through Integrated Design. CTBUH $\mathrm{J}$.

Sekhar, S.C., 1995. Higher space temperatures and better thermal comfort - a tropical analysis. Energy Build. 23, 63-70. doi:10.1016/0378-7788(95)00932-N

Simmonds, P., Holst, S., Reuss, S., Gaw, W., 2000. Using radiant cooled floors to condition large spaces and maintain comfort conditions. Flack+Kurtz Consulting Engineers, San Francisco, CA (US).

Simmonds, P., Mehlomakulu, B., Ebert, T., 2006. Radiant Cooled Floors -- Operation and Control Dependant upon Solar Radiation. ASHRAE Trans. 112, 358-367.

ASHRAE Standard 55 and User's Manual | ashrae.org [WWW Document], n.d. URL

https://www.ashrae.org/resources--publications/bookstore/standard-55-and-user-s-manual (accessed 7.24.17).

Stetiu, C., 1999. Energy and peak power savings potential of radiant cooling systems in US commercial buildings. Energy Build. 30, 127-138. doi:10.1016/S0378-7788(98)00080-2

Tang, H., Liu, X.-H., Jiang, Y., 2016. Theoretical and experimental study of condensation rates on radiant cooling surfaces in humid air. Build. Environ. 97, 1-10. doi:10.1016/j.buildenv.2015.12.003 
Watson, R. and Chapman, K., 2002. Radiant heating and cooling handbook. McGraw Hill Professional.

Zhang, T., Liu, X., Zhang, L., Jiang, J., Zhou, M., Jiang, Y., 2013. Performance analysis of the airconditioning system in Xi' an Xianyang International Airport. Energy Build. 59, 11-20. doi:10.1016/j.enbuild.2012.12.044

Zhao, K., Liu, X.-H., Jiang, Y., 2014. On-site measured performance of a radiant floor cooling/heating system in Xi'an Xianyang International Airport. Sol. Energy 108, 274-286. doi:10.1016/j.solener.2014.07.012

Zhao, K., Liu, X.-H., Jiang, Y., 2013. Application of radiant floor cooling in a large open space building with high-intensity solar radiation. Energy Build. 66, 246-257. doi:10.1016/j.enbuild.2013.07.014 